Covered in: ERIH PLUS, CEEOL, Index Copernicus, CrossRef, CrossCheck, J-Gate, Google Scholar, Ideas RePeC, Econpapers, Socionet, KVK, WorldCat.

2018, Volume 6, Issue 2, pages: 37-41 | doi: https://doi.org/10.18662/lumenphs/09

\section{The Atmosphere of Antim Monastery in Valeriu Anania`s Memorii}

\author{
Adrian BĂRBIERU1 \\ ${ }^{1}$ Bucharest, Romania, \\ adrian.barbieru@yahoo.com
}

\begin{abstract}
Valeriu Anania is the first Bishop that had the courage to publish an autobiography volume called Memorii (2008). The volume presents the atmosphere in Antim Monastery before the movement Rugul Aprins. Anania became a monk during the Second World War. The lively scenes presented to the reader do not correspond with the seriosness which is usually asociated with the monastic life. The author tells his life in a very bright way, with humour, avoiding promiscuity and human degradation in the Second World War.
\end{abstract}

Keywords: Antim monastery; Valeriu Anania; biography.

How to cite: Barbieru, A. (2018). The Atmosphere of Antim Monastery in Valeriu Anania`s Memorii. Logos Universality Mentality Education Novelty: Philosopby \& Humanistic Sciences, 6(2), 37-41. https://doi.org/10.18662/lumenphs/09 
In his Memorii, Valeriu Anania openly writes about his life even if his talent was hidden under his monastic vocation, succeeding to connect literature with theology. At the end of his life he became Bishop of ClujNapoca and he had the courage to publish his autobiography called Memorii (2011). In his life we become witnesses for three types of worlds: the world before dictatorship, the totalitarian age and the spring of democracy.

Eugen Simion (2002: 12) says: , in his memoirs the author tells a story about himself, but he talks especially about the world that he is going through".

Alexandru Paleologu remarks that memoires it is not a plural of memories but „of memoirs, which is an account about an important phenomenon, about which you know how it was made.... writing memoires is an imagination work. This means that you can create a world into another world, an imaginary one, with much more power and consistency than the real one" (Paleologu, 2005: 53).

The Antim period is connected with his youth from the beginning of the 40s. It is coincided with the First World War. On February $2^{\text {nd }} 1942$ he became a monk at the Antim Monastery in Bucharest, where he received the name Bartholomew. In the same year he meets Tudor Arghezi who remained his friend for 25 years. Anania became his disciple. His first poem In singurătăți was published in a famous magazine Gandirea.

Entering the monastery certainly was a crucial moment in his life: „Why I did it, I cannot say. I often wondered, looking behind, if not because I was afraid of war, if not because I was afraid of life, if I was imitating Arghezi in pursuing adventure. Anyway it is certain; I did not do it out of vocation". (Anania, 2011: 42)

He came to the monastery with an idyllic idea about monastic life. He remained only a short time in Antim. He left because he could not find himself in this world.

Looking back he reflected the people who lived there „did not feel connected to each other, their life in common seemed to be a simple random meeting, like in the army or in jail, and soon I started to have pity on those people, who gathered without knowing, who lived without loving each other and who died without complain" (Anania, 2011: 51).

Soon after his departure, Daniil Sandu Tudor founded the movement Rugul Aprins. It s aim was „, a rediscovery of an ability to perceive the world in a theological way, which opens the path to a real perception of the spiritual values" (Jinga, 2005: 67).

Valeriu Anania was not a member of Rugul Aprins. Andree Scrima explains Anania s relation with the Rugul Aprins: 
It was told sometimes talking about another man of the church that Father Bartholomew Anania, who meanwhile became Bishop, would have had strong connection with the Antim Gathering. The general rapports of normal friendship- he was back then head librarian of the Patriarchy-existed with anyone around... One time we remember that we assisted with $A l$. -Mironescu and $d r$. Vasile Voiculescu, Constantin Jora at a lecture read by Father Anania of a popular play written by bimself (Scrima, 1996: 161-162).

In his work Anania described life at Antim monastery in a colourful way. The lively scenes presented to the reader do not correspond with the seriousness which is usually associated with the monastic life. The writer decides to remain hidden even if he evokes events which he witnessed. $\mathrm{He}$ even talks about events that he lived and incarnated. The first image has a special plasticity. This presents the main character, the Abbot, Eugen Laiu. In this image, Anania shows a special sense of humour:

The abbot did not have much education. He was an excellent working man, he had a practical intelligence, but he proved to be a gossip, extremely nagging and sometimes rude. He talked all day about anything, le liked to gossip about others, he laughed like a horse. He was harsh on the students, he counted their working hours and minutes, be put an attendance sheet at the church to see who would skip the Mass, he got angry quickly and swore. I could not understand how is it possible that he could say to Father Ghedeon, jack ass", and Ghedeon bowed, kissed his hand and said "Bless me, Father and forgive me". These scenes happened almost daily and I was witnessing them astonished" (Anania, 2011: 44).

The second significant moment in the Antim period remains the scene with the young lady, with blue eyes, always decently dressed, who always attended the mass, who falls in love with the young monk. He presents a scene which has a shocking honesty for a man of the Church:

Springs always got me with flues and tonsilllitis. In that evening I was not going to the pew and I was listening to the evening mass, standing at the entrance. Afterwards I went to buy some medicine. I was turning back on a very poorly lit street when I met the young lady. It seemed like she was expecting me. She said "good evening" and started gently a general conversation. Then she suddenly changed and she started a pathetically, almost tragically, a love confession. I freeze. I was not looking around because I was afraid that someone would see me or hear 
her. Her eyes were bright in tears. I, eventually, told her that I was astonished that I hear all these from such a faithful person and I found out that for several weeks she was praying to God to give her one day or one hour with the unknown monk. I felt my cheek touched by a trembling hand and I ran away on the empty street, to the church gate. I bave not seen her since (Anania, 2011: 48-49).

Talking about this biographical piece of literature Stefan Cazimir underlines: "We can see, even from the beginning, that V aleriu Anania existence seems made out of literary models and that he, eventually, will excel in literature".

This is perfectly true because Anania succeeded to turn this woman into a character. Over the years: „From this true event will increase, later on, Iovanca in his play „Mesterul Manole” (Anania, 2011: 49)

The third defining moment in the book takes place when Colonel Demetriu convinces him to keep a package, promising that there it is nothing compromising in it. The Colonel sympathised with the extreme right Iron Guard and he had hidden in the package magazines like Buna Vestire and Cuvântul. Unfortunately, he lied. He hide in the package legionary publications and a gun. After his departure from Antim he takes the package to Monastery Polovragi. There, he receives, by mistake, a telegram which was sent to the head of the post with the message: „Arrest and escort the monk Anania Bartholomew" (Anania, 2011: 63).

To the astonishment of the head of the post, Anania turned himself willingly to the military Martial prosecutor on Negru Voda Street. This one looked at him like a ,ghost". He could not believe it. Anania was arrested because of the content of the package.

From the Individual Tracing File found in the National Council Archive for Studying the Security Archives (DUI, 1450) we find out that Anania was set free because Patriarch Nicodim intervened with the central authorities. He was freed in 1958 but soon afterwards arrested again and accused for being legionary. He was freed 6 years later with the general amnesty of 1964.

In conclusion, the time Anania spent in Antim is connected with the Second World War, marked by the end of Great Romania, hunger, collective and personal tragedies. On this sombre stage, the author tells his life in a very natural way, with bright colours, with humour, not giving in to promiscuity and human degradation.

\section{References}

Anania, B. V. (2011). Memorii [Memoirs]. Iaşi, Romania: Polirom. 
Cazimir, S.. (2009). Ce straniu poate fi destinul unui om [How strange can the destiny of a man be]. România literară, 6/13 februarie, 10. Retrieved from http://www.romlit.ro/index.pl/ce straniu poate fi destinul unui om

Jinga, C. (2005). Ieroschimonabul Daniil Sandu Tudor. Omul și opera [Hieroschemamonk Daniil Sandu Tudor. The man and his work]. Bucharest, Romania: Chistiana.

Paleologu, A. (2005). Breviar pentru păstrarea clipelor [Roundup for keeping the moments]. Bucharest, Romania: Humanitas.

Scrima, A. (1996). Timpul rugului aprins [The time of the lighten stake]. Bucharest, Romania: Humanitas.

Simion, E. (2002). Genurile biograficului [The biographical genres]. Bucharest, Romania: Univers Enciclopedic. 